\title{
Chapter 5 - Twenty-First Century Workforce Demographics and New Challenges for An Egalitarian Society
}

\section{Dr Sharman Stone MP, Minister for Workforce Participation}

\section{Lecture presented 30 August 2006}

Let me begin right up front by acknowledging the traditional owners of this part of this country. I think it is a very important protocol now to establish and recognise the traditional owners. One of the things I was very pleased to do was to represent the Government on the Council for Aboriginal Reconciliation for three years because my earliest writings were about Australian race relations.

I have to say that I cannot be more pleased with the Ministry I have, Workforce Participation, because all of my working life and all the time I have spent in Universities has been working to try and overcome disadvantage. For example, I have worked in prisons with, in particular, Aboriginal prisoners and I have worked in very small communities as a community development officer, in the days when we had the Australian Assistance Plan in the 1970's. I will never forget when I walked in to this job interview on the first day after my university graduation and they said, 'your job will be to empower the people'. For me that was just what I felt it was all about - I wanted to empower people.

We are at a time in Australia where we facing a number of important challenges and where we need to respond with real changes. I hope that tonight we can have a conversation and have questions and statements from the floor so I can hear your views. I promise I will not talk forever. Clearly no Government has got all the answers. Reform is an evolutionary process and what better place to have this conversation than in a university, like this.

Let me begin by saying how I define egalitarian society. This is where individual status is achieved, not ascribed at birth, and where there is no institutional support for creating or perpetuating a stratified society. We have such a society in Australia and we're proud of it. We are a society that aims to give everyone a fair go. This is not to say of course, that it is not much harder for some than others to reach their full potential. It depends a great deal on your birth and your family's circumstances. For example, it is much harder to achieve in Australia if there is no breadwinner in the family and where there hasn't been one in several generations of the family. It is much harder to achieve your full potential if your family is not English speaking or not literate. It is much easier 
to have access to good educational facilities if you are born into a better off family than if you are born into one that is disadvantaged.

It is my job as Minister of Workforce Participation to help disadvantaged Australians to achieve their potential, to help the long term unemployed and the disadvantaged from being condemned to depression, social isolation, stigma, exclusion or discrimination. Society measures individuals by what they do in the form of paid employment.

Bruce Headey, from the Melbourne Institute, has done a lot of work on the impact of joblessness. He found that while joblessness was a transitory phenomenon for many households, there were significant numbers of households which were persistently jobless.

Indeed, in any given year, around 16 per cent of working age households are jobless in Australia. Nearly 10 per cent of these experience persistent joblessness for three years or more. Single parents are twelve times more likely, and people with a disability six times more likely, than the rest of the community to be persistently jobless. We have about 600000 children growing up in households where no member of the family is in employment. Joblessness often couples with poverty, financial stress, depression and poor physical and mental health. Joblessness also causes a twofold increase in the chance of marital break up and halves the chance of ever partnering or re-partnering.

It goes without saying that our welfare system needs to be comprehensive and generous enough to provide an adequate living for those without their own means of support because of, for example, old age or because they are too sick or disabled or have parental responsibilities without a supporting partner. Obviously in a society like ours it is fundamental that we have a safety net and that we help those who are not able to support themselves. However, over the last few decades, our welfare system in Australia has slipped out of alignment with expectations and community practices. Some elements of the welfare system have created disincentives for people to move from welfare dependency and into paid employment.

To put this in context, Australia has enjoyed over a decade of economic growth. With the Government's reforms since 1996, we are living in an economic climate of low inflation and low interest rates. The unemployment rate is at 30 year lows and we have experienced nearly 17 per cent growth in real wages. More than 10 million Australians are now in work, 7 million of them in full time work. Over 1.9 million jobs have been created since 1996 and long term unemployment has fallen from 197,000 in March 1996 down to 95,000 now - about a 52 per cent decrease. It is fantastic, indeed it is!

However, there are also around 2.5 million people of working age in Australia that are receiving working age welfare payments. Of those, about 500,000 of are 
officially unemployed, receiving the Newstart payment and required to look for work. The other two million people are receiving pensions, and are not required to look for work, made up of about 700,000 people receiving the disability support pension and around 600,000 receiving parenting payments, the large majority of whom are single women. Amazingly, despite the fact that we have not had a huge number of workplace accidents or a shocking deterioration of health standards in Australia, the number of disability support pension recipients has grown by over 60 per cent in the last 11 years such that the cost to the taxpayer of disability support pension payments is now around eight billion dollars per annum.

Now, of course, besides the concern I hope I have expressed to you about the personal impact of unemployment on the individual, unemployment is not a benign experience. Long term unemployment poses real risks of social isolation for families, particularly where it becomes intergenerational. One challenge that we face is that many jobs are not advertised.

I was in Ballarat yesterday and I found that 70 per cent of employers have a preference for word of mouth as a means of employing people. Something like 60 per cent of job vacancies in Ballarat are not advertised. If you do not have any member of your family in your household that is in work, then you are outside the loop for hearing of or knowing where many of the jobs are. You do not hear about the new maternity leave vacancy because your mother and grandmother are not in work. You do not hear about the new apprenticeship vacancy that has come up at your uncle's place of work. Employer's preference for word of mouth, and not advertising their job vacancies, makes it extraordinarily difficult for our unemployed to get a job, particularly where they do not have a network, such as through members of their family, that can speak on their behalf and help them find work. One product of these circumstances is intergenerational unemployment. Work ethic is a learned behaviour just as parenting is. If you are not aware of what it takes, what you have to do, how to present in a job interview and what is expected of you at work, it becomes very challenging for you to succeed in a job without assistance. It is very difficult for children to learn appropriate work ethic when they are living in a jobless family and this substantially increases their chances of being unemployed themselves.

While we are concerned about the impact on individuals and families of unemployment, we are also concerned with the declining ratio of those in work compared to receiving working age welfare. The balance between tax payers and dependent welfare claimants has shifted from the 1960's, when three per cent working age population was on welfare, to around 17 per cent today. In the 1960's there were 22 tax payers supporting one person on welfare. Today, this ratio has collapsed to five tax payers for every one welfare dependent person. 
If this trend continues, we will be down to two to one in a decade. Based on current trends, we cannot sustain this level of welfare spending.

A further challenge we are facing is Australia's ageing population. The baby boomers, and I am just on the cusp of a baby boomer generation, are reaching retirement age. Our natural population increase has not kept up with the baby booming numbers and we do not have a substantial number of new births pushing up behind the baby boomers. This is a problem afflicting many countries. In Japan, UK, USA and New Zealand, we are all asking, 'How are we going to fix this problem and sustain our economy?'

We obviously need sufficient human capital to maintain our economic strength and keep our business sector growing. We have had recent surveys done by the Reserve Bank, and an ageing workforce consistently rates as a first or second order issue for large sized enterprises. Some people keep talking about the 'skills' shortage. However, the point is that it is not just at the skilled end, it is our entire labour force. We have shortages in the trades and in the tertiary qualified highly skilled end of the market. We have a huge shortage in the health sector and also in engineering, particularly mining. But we also have a significant shortage in entry level positions particularly in the retail, manufacturing, hospitality, tourism and agriculture sectors. So a lot of businesses are constrained in their further growth because they cannot get workers.

The Department of Employment and Workplace Relations (DEWR), my department, recently asked Monash University to do some analysis on the workforce for us. We had the Intergenerational Report, that Peter Costello launched, which gave us a longer term look at these issues, but the Monash Research, entitled Workforce Tomorrow, had a five year forward look the trends in our workforce. It projects a 195,000 person workforce short fall in the next five years across all sectors. Just as significantly in numbers in the retail, manufacturing, hospitality, tourism, agribusiness and in areas of trades and other specialties.

So what are doing about all of this? We have three policy drivers for how we tackle our current situation. In 1996, when we were elected, we had the Commonwealth Employment Service, a public sector operated service. When we came to office, we felt that it was not good enough nor performing well enough so we immediately began to look at better ways of assisting the unemployed into work. First thing that was introduced was Work for the Dole in 1997. People were very concerned about this. They said, 'That's shocking, using the dole to stigmatise and label people and what's this mutual obligation business?' In fact, our Work for the Dole program has been extraordinarily successful. 42 per cent of our participants in the programme, after six months, are either in work or are directed into employment related training. 
In 1998 we also introduced the Job Network program, and this was a revolution, a very bold move. It was all about providing Australian Government Employment Services, through a contracted out model, in a competitive environment where providers are paid on outcomes, for putting the unemployed into jobs. A ratings process, called Star Ratings, are used to track the progress of providers so when a new tender round comes through we have a way of rewarding the better providers.

It had been extraordinarily successful. In the last six months, Job Network Providers have placed more people in jobs than the last six years of the Commonwealth Employment Service (CES). I am not saying that it is as good as it can be, but it is evolving and I am certainly working very hard to ensure that administration and bureaucracy is at a minimum and that we remove any perversities in the incentive structure from the Job Network program in order to have people placed into jobs as soon as possible.

Job Network is just one part of it, there is also the Disability Employment Network, Vocational Rehabilitation Program and the Personal Support Program, which helps those who are jobless but also homeless and who may face other barriers such as drug and alcohol dependency or mental illness. We also have a youth programme, Job Placement Employment and Training (JPET). There are nine separate programmes in Australia, a constellation if you like.

These programmes form the structure through which we are delivering Welfare to Work but let me outline the policy basis behind this structure. As I said to you, we have this incredible trajectory of increasing disability support pensions. We also have significant underemployment, compared to the Organisation for Economic Cooperation and Development (OECD), of our parents on pensions. We are still amongst the lowest in the OECD countries in terms of the employment rates of people receiving disability benefits and there are sixteen other countries that perform better than us. We have the third highest rate of jobless families in the OECD.

We do not have a very good record compared to other OECD countries, which is why we are doing things differently now. On the 1 July 2006, we implemented our Welfare to Work reforms. If you were a parent on Parenting Payment, single or partnered, in the past you were allowed to stay on that payment until your youngest turned 16. This caused problems because by that stage, women in particular, their skills were rusty as they have been out of the workforce for a long time. By the time the youngest was 16, a lot of parents felt that there was not much hope at all of re-entering the workforce.

So now since 1 July, when your youngest reaches six, you will go to Centrelink who will sign you to a Job Network or Disability Employment Network provider and we will give you every support to upgrade your skills. You can, for example, go and get a nursing qualification or teaching or whatever you like and you will 
continue on the pension until your youngest is 8 . But if you have not got a job by then, you will be transferred you onto an unemployment payment, Newstart.

We believe that in the current environment, if you are really trying you will be employed within those two years. We are making sure that there isn't a problem with your childcare and we have put conditions around what is a suitable job. For example, parents will only be required to accept the job if it is appropriate, if there is access to affordable childcare, it is not more than an hour away from where you are living and that you clear at least $\$ 25$ a week more than the pension or allowance you were on. That is, on the minimum wage, being $\$ 12.75$ per hour, if you are working the minimum 15 hours a week, you are still $\$ 4500$ better off a year working than if you stay on the pension. And of course that is just the monetary advantage. When we survey people, they tell us all the time, particularly parents, 'It is not the income, I want to work and I want to get back and build my own independence, rebuild my networks and get back in touch with where I was'. So our parents are going to be substantially better off than before.

With Disability Support Pensioners (DSP), most of our people on DSP are mature age men with skilled backgrounds but who have muscular skeletal problems which put them on to DSP. In the past to get on DSP you went to your Doctor and then took a medical certificate to Centrelink, who granted you the DSP. In other words, if you couldn't work part time, we parked you on DSP until you reached Old Age Pension age. This is very bad for people, particularly for those with depression, anxiety and/or phobias. We know through extensive Australian research that the best thing you can do for people with a mental illness is help them back in to the workplace, a supportive workplace.

This has all now changed. Of course the people on DSP before 1 July are 'Grandfathered' and their situation doesn't change. But from 1 July 2006, if you present with a medical certificate you will be then referred to a Job Capacity Assessment with work specialists and rehabilitation specialists and they will assess how many hours you can work. If you can work in a job at least fifteen hours a week, then you will receive Newstart not DSP, and we will very actively help you be upskilled, supported back into the workplace and we will work with employers to ensure they understand your condition. We will give you every opportunity to work. For example, we can provide workplace modification grants, which can be used to put in a ramp, change your lighting and change your software. We have also implemented a Supported Wage System. If you are assessed as being only 60 per cent productive because of your impairment, through the Supported Wage System, the Government conducts a special assessment process and the employer will not be required to pay more than 60 per cent of the award wage. 
I mentioned to you the preferred employment process in Australia is word of mouth. We want people to think outside the square and take the risk of employing people they may not know. Our industrial relations reforms have made this much easier, particularly with the removal of unfair dismissal laws. They have also made it much easier to have a part time job or work at home.

We believe through these changes that we are giving our 2.5 million Australians of working age on welfare a better chance. We are not prepared to sit back in our society and say, 'Well let's hope that somehow they get themselves a job.' We know that unemployment can be intergenerational. We know that unemployment leads to stress and pressure on families and individuals. We know we have an ageing population and that we have to do something about increasing our workforce participation in Australia. Finally we have that issue of the declining ratio of welfare dependent working age persons to tax payers and we have to think very seriously how we redress the decline.

So I will leave it there. I have not talked much about our Indigenous Australians, who as many of you know have a much harder time with intergenerational unemployment and higher unemployment rates than others. We have to get rid of the idea of sit down money in remote communities where there is work. We are also looking closely at our humanitarian refugees that also experience higher rates of unemployment. I have a special focus on how we are going to support them in to work, particularly by improving the teaching of English to these groups.

Let me finally say to you that we are an egalitarian society and across our great nation there a lot of people who are not reaching their full potential. As Minister of Workforce Participation, my aim is to make sure that our Government is able to do more and to do better for people who deserve better. 